\title{
Defining Cyborg Intelligence for Medical and Super-Human Domains
}

\author{
Md Sadique Shaikh* \\ Institute of Management \& Science (IMS), India
}

Submission: May 31, 2018; Published: July 05, 2018

*Corresponding author: Sadique Shaikh, Institute of Management \& Science (IMS), India, Email: sids_nsk@rediffmail.com

Keywords: Engineered; Electro-Mechanical Artificial; Cybernetics; Bionic Devices; Medical Robotics

\section{Short Communication}

First get to know what is a Cyborg? It's an organism that has both organic ("natural" GOD made) and cybernetic ("machine" Electro-Mechanical Artificial and Man Made) parts engineered, implemented and cascaded in Human body for Biological medical assistance or to change ordinary human potentials, capacities and intelligence to super or ultra-power levels. In other words, when people become Cyborg, they're part human and part machine. Below diagram clear the seen in depth.

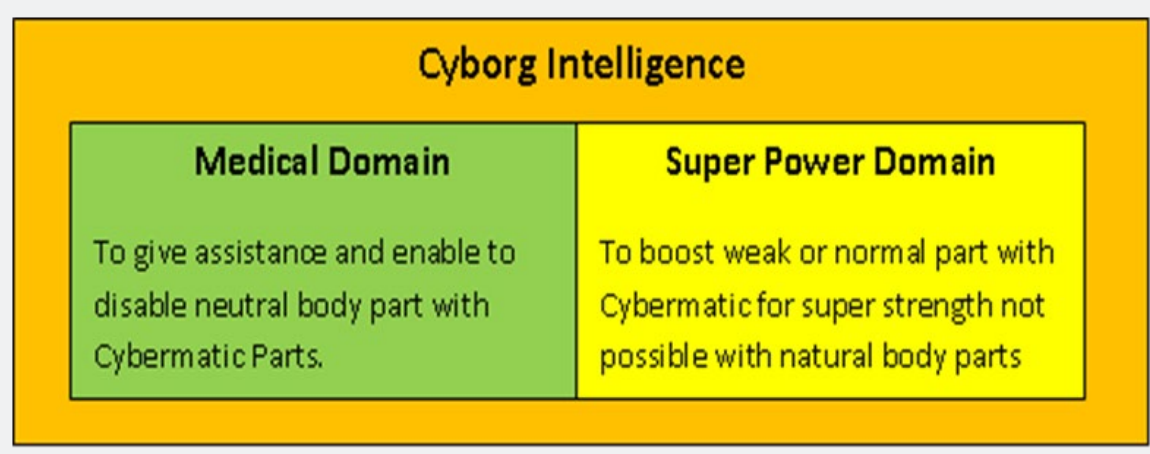

Figure 1: Cyborg Intelligence.

In above Figure 1 (model I) split further Cyborg Intelligence into two domains as Medical Domain and Super Power Domain. The first domain Cybernetics organs are needful, but the second domain is completely desired of mankind to give exceptional abilities to body and mind. In medical domain now,adays designing and engineering in process to give next advanced level to Artificial limbs, joints, spinal, legs, fingers, hands, arms, etc either to replace disable natural organs or to support weak organs of human body. Where as in second Super Power domain its wish of mankind to convert their Natural organs with extra ordinary power, vision, intelligence, movements with implementing cybernetics organics like third back electronic eye at the back of head for back vision additional ability along with front natural and normal ability artificial legs to in reverse and forward direction and Brain-Computer Interfaces (BCI) for ultrahigh intelligence with coupling Natural Intelligence
(NI God made) with Artificial Intelligence (AI Man made) etc. for successful Cyborg Technology implementation must need sophisticated and precise Bionic Engineering [1]. We can define term Bionic as "Its utility of Biological methods, function, procedures and system to interface or mimic electronically". The term Bionic coined by Jack E. Steele in 1958.It's very vast field to conduct good research on Bionic and Bionic Devices Interfacing for the enhancement of Medical Robotics. For Bionic system engineering excellent tradeoff of Biological and Electronics system required and can be obtain with linking of Artificial Neural Schemas with Biological Neural schemas $[2,3]$. As per my strong research area in "Bionic Brain" since last seven years I must say this is the only field of robotics which direct concerns to medical betterment. With worked on "Neuron- Command Operating Devices" where seen under gone through several excellent references which can be used 
by young researcher as to review and resume their research in the field. Using NCOD several artificial parts can be synch with Biological parts and work coordinative for proper body functioning, gestures, postures, movements and inter pretation. Using this facility not only part can replace but also additional parts can be implemented to give human ultra-intelligence facilities like Bionic eyes, ear, and additional artificial brain modules. Cyborg is another possibility in Medical as well as super artificial power domains [4]. Cyborg "Cybernetic organism" is a being with both organic and Biomechatronic body parts using which human can increase their power in all means and branch of study is "Cyborgology" [5].

\section{Conclusion}

With the help of this short communication I tried to understand what engineering parameters and steps are important and where haveto change from routine AI engineering for Cyborg technology implementation in Medical and Super power domains with discussing.

\section{Acknowledgment}

I really thankful to my wife Safeena Shaikh for her moral support my son Md. Nameer Shaikh for his love which keeps me fresh with new ideas and my close friend Tanvir Sayyed for her positive support with me and my motivator Dr. B.N.Gupta for his constant support.

\section{References}

1. NSF/EC Understanding on Co-operation in Information Technologies Strategic Research Workshops IST-1999-12077.

2. Md. Sadique Shaikh (2013) Analysis and modeling of Strong A.I to engineer BIONIC brain for humanoid robotics application. American Journal of Embedded System and Applications, Published by Science Publishing Group, New York, America 1(2): 27-36.

3. Md. Sadique Shaikh (2017) Ultra Artificial Intelligence (UAI): Redefining AI fir New Research Dimension. Advanced Robotics \& Automation (ARA), OMICS International, London, UK 6(2): 163.

4. Md. Sadique Shaikh (2017) Fundamental Engineering for BrainComputer Interfacing (BCI): Initiative for Neuron-Command Operating Devices. Computational Biology and Bioinformatics (CBB) 5(4): 50-56.

5. Md. Sadique Shaikh (2018) Defining ultra-artificial intelligence (UAI) implementation using bionic (biological-like-electronics) brain engineering insight. MOJ App Bio Biomech 2(2): 127-128.

\section{Your next submission with Juniper Publishers will reach you the below assets}

- Quality Editorial service

- Swift Peer Review

- Reprints availability

- E-prints Service

- Manuscript Podcast for convenient understanding

- Global attainment for your research

- Manuscript accessibility in different formats ( Pdf, E-pub, Full Text, Audio)

- Unceasing customer service

Track the below URL for one-step submission https://juniperpublishers.com/online-submission.php 